\title{
Selenium content in soils from Murcia Region (SE, Spain)
}

\author{
C. Pérez-Sirvent ${ }^{\mathrm{a}}$ *, M.J. Martínez-Sánchez ${ }^{\mathrm{a}}$, M.L. García-Lorenzo ${ }^{\mathrm{a}}$, J. Molina ${ }^{\mathrm{b}}$, M.L. Tudela ${ }^{\mathrm{b}}$, \\ W. Mantilla ${ }^{a}$, J. Bech ${ }^{\mathrm{c}}$
}

${ }^{a}$ Department of Agricultural Chemistry, Geology and Pedology, Faculty of Chemistry, University of Murcia, Campus de Espinardo, Murcia, Spain

${ }^{\mathrm{b}}$ Department of Physical Geography, Human Geography and Regional Geographical Analysis, Faculty of Geography, University of Murcia, Campus de La Merced, Murcia, Spain ${ }^{\mathrm{c}}$ University of Barcelona, Barcelona, Spain

Keywords:

Selenium

Generic reference level

Soil pollution

Murcia Region

\section{a b s t r a c t}

The objective of this study was to determine the selenium content in soils from the Region of Murcia (SE, Spain) and to study the possible relationship between mineralogical composition, soil properties and selenium content. In addition, generic reference level (GRL) for selenium was determined according to Spanish legislation. For this study, 490 samples were selected in areas subjected to agricultural activity or abandoned agricultural soils with natural vegetation. Five different zones were established in order to study selenium variability. Four different mineralogical groups were established, based on significant relationship with the mineralogical composition, and each sample was included in one mineralogical group. The results showed that the concentration of selenium is correlated with the electrical conductivity, sulphate content and with the mineralogical composition, particularly positively with quartz and in a negative way with calcite percentage. In addition, selenium level was positively correlated with the phyllosilicate content. Established GRL for selenium varies with the mineralogical group, having a great transcendence from the legal and economic points of view.

\section{Introduction}

Selenium is a chalcophile non-metallic element forming several rare minerals, but is more widely present as an accessory element replacing sulphur in the common sulphide minerals, such as pyrite or sphalerite. Selenium mainly occurs as insoluble elemental $\left(\mathrm{Se}^{0}\right)$ and selenide $\left(\mathrm{Se}^{-2}\right)$ forms, but in oxidizing environments such as aerobic soils, the element is converted to soluble selenite $\left(\mathrm{Se}^{+4}\right)$ and selenate $\left(\mathrm{Se}^{+6}\right)$ forms, selenate being predominant at alkaline $\mathrm{pH}$. Selenium is an essential nutrient for humans and animals (Schwartz and Foltz, 1957), even if it is not required by plants. The harmful effects and toxicity mechanisms of selenium have been discussed extensively (Lauchli, 1993); however, some reports indicate that selenium may positively affect plant growth at low concentrations (Xue et al., 2001). At low concentrations it acts as an antioxidant and stimulates plant growth.

Background and baseline values for trace elements in soils can act as a true reference level for estimating the extent of soil pollution with these elements (Horckmans et al., 2005; Ferguson, 1990). However, more importantly, knowing them can help in defining areas which need further study because of likely anthropogenic influences.

* Corresponding author. Tel.: +34868887449; fax: +34968364148. E-mail address: melita@um.es (C. Pérez-Sirvent).
Background values can be defined as the natural concentration of heavy metals in soils without human influence (Adriano, 2001; Salminen and Gregorauskiene, 2000). On the other hand, baseline values express the upper limit of the range of concentration covering, as a function of a predefined statistic, the natural variability associated with the background levels of certain elements or compounds at a regional level. Baseline values in agricultural soils correspond to total concentrations of heavy metals in soils not influenced by point input due to local human activities (e.g., industries) but include diffuse or non-point input (e.g., atmospheric deposition and fertilization) (Micó et al., 2007).

Background and baseline values are highly dependent on the mineralogical composition of the parent material and on the weathering processes that have led to the formation of the soil (De Temmerman et al., 1984; Su and Yang, 2008) and also on grain size (Salminen and Tarvainen, 1997), clay, and organic matter content (Klassen, 1998; Tack et al., 1997). Geochemical maps are of great interest because they constitute an effective tool for environmental planning (Ferguson and Kasamas, 1999; Martínez et al., 2007). Geochemical mapping allows discriminating between anthropogenic pollution and natural (geogenic) sources (Albanese et al., 2007).

Some countries, as Spain, have developed a legislation to define soil pollution reference levels. At a national level application, the Spanish Royal Decree (9/2005), of 14 January, establishes a list of potentially soil contaminating activities and criteria and standards for declaring contaminated sites. This decree proposes the establishment 
of generic reference level (GRL). Generic reference level (GRL) is a basic parameter used for assessing soil contamination for specific substances. Generic reference level is defined as "the concentration of a contaminant in soil that does not result in a level of risk higher than the acceptable maximum for human health or ecosystems".

"Generic reference levels for trace elements could be determined as adding to the mean concentration twice the standard deviation of concentrations existing in soils nearby areas that are not contami- nated and have geological substrates with similar characteristics. Values calculated for metals shall constitute a single set and shall apply for any land use and be valid for both the protection of human health and ecosystems".

"If contaminant concentration exceeds 100 or more times the established GRL, the environmental competent organism could declare the soil as contaminated, without carrying out a Risk Assessment” (Spanish RD, 9/2005).

To apply this legislation, the selection of the sampling areas is fundamental. Potentially soil contaminating activities are located mainly in plain areas or areas with scarce slope, over colluvial or alluvial soils, with a Quaternary origin, being a mixture of lithologic materials from surrounding mountains, and not in pure lithologic units. Then, in order to determine GRL, the sampling design could not be a systematic sampling of all the territory based on geologic or soil maps. In this case it is necessary to develop an ad hoc sampling method.

The objective of this work was, on the one hand, to study the selenium content in agricultural soils or abandoned agricultural soils with natural vegetation not subjected to particular point contamina- tion sources, in the Region of Murcia (SE, Spain) and to study the possible relationship between soil properties, mineralogical compo- sition and selenium content in soil samples. On the other hand, the purpose of this paper was to determine generic reference levels (GRLs) for selenium according to Spanish legislation and to study the possible influence of soil composition in these levels.

\section{Material and methods}

\subsection{Studyarea}

Murcia Region is located in the southeast of the Iberian Peninsula, with a surface of $11317 \mathrm{~km}^{2}$, and characterised by semi-arid climate. The average temperature is $18.5^{\circ} \mathrm{C}$ and precipitation ranges from $150 \mathrm{~mm}$ to $400 \mathrm{~mm}$, with an average value of $325 \mathrm{~mm}$.

The Region of Murcia belongs to the Betic domain that extends from Cadiz to the Balearic Islands. The Prebetic is represented in the north of Murcia Region and is constituted by Mesozoic and Tertiary materials, affected by tangential tectonic processes. The Subbetic exists in the central part of the Region; their materials pertain to the Mesozoic and the Tertiary periods and they have suffered intense compression processes. The internal zones are represented in the south of Murcia Region and are constituted by Paleozoic and Triassic materials, which have suffered regional metamorphism and impor- tant tectonic processes. In the internal zones, Nevado-Filábride, Alpujárride and Maláguide complex are represented in the studied area. In addition, there are basins filled up with marine materials during Miocene and Pliocene. These basins contain sedimentary rocks, essentially marls, conglomerates and calcarenites. Finally, the area shows vestiges of postorogenic volcanic activity, in general with basic or intermediate composition.

Murcia Region is lithologically characterised by limestones, dolostones, marls and metamorphic materials, mainly phyllites.

The predominant soils in Murcia Region (CARM, 1999) (Fig. 1) have a carbonated nature, mainly Xerosols, Litosols, Regosols and Fluvisols (Martínez-Sánchez and Pérez-Sirvent, 2007). In the studied areas, predominant soils are calcic and petrocalcic Xerosols, calcaric, lithorhodic and lithosolic Regosols and calcic Fluvisols.

\subsection{Sampling method}

The sampling sites corresponded to areas subjected to agricultural activity (85\% of the samples) or soils with natural vegetation, which correspond to abandoned agricultural areas (15\% of the total samples) (Fig. 2).

Five zones were established as a function of physicochemical characteristics, crop types, potentially soil contaminating activities, geomorphological characteristics and population density. These areas were selected in previous studies showing differences in the trace element content (Martínez-Sánchez and Pérez-Sirvent, 2007).

Sampling sites were disposed in a $3 \mathrm{~km}$ square grid and the sampling density was 1 sampling site per $\mathrm{km}^{2}$, but some particular locations were excluded due to (Martínez-Sánchez and Pérez-Sirvent, 2007):

- potential contamination due to the presence of industry or rubbish dumps;

- surrounding mountainous areas, without industrial activity, as established by the Royal Decree 9/2005;

- mining areas with a high anthropic influence. In these areas it is very difficult to differentiate between anthropic and geogenic concentrations.

This sampling design permits to reduce the number of sampling sites, because areas with unfavourable topographical or infrastructure conditions were excluded, as established by the Spanish legislation (Spanish RD, 9/2005). Finally, a set of 490 representative samples was used and distributed in five zones (Fig. 3).

Soil samples were collected from the surface soil $(0-25 \mathrm{~cm})$. Five subplots $(25 \times 25 \mathrm{~cm})$ for soil sampling were selected at the corners and the center of the plot $(1 \times 1 \mathrm{~m})$. Soil samples were collected with a shovel in each subplot, then mixed and homogenized and a subsample (about $2 \mathrm{~kg}$ ) was taken (Pérez-Sirvent et al., 2009).

\subsection{Chemical analysis}

The samples were air dried and sieved to $\mathrm{b} 2 \mathrm{~mm}$ for general analytical determinations. The $\mathrm{pH}$ was measured in a 1:5 suspension of soil in ultrapure water (Milli-Q). Electrical conductivity (EC) $\left(\mathrm{dS} \mathrm{m}^{-1}\right.$ at $25^{\circ} \mathrm{C}$ ) was measured in the extracts obtained by filtering the 1:5 suspensions through a $0.45 \mu \mathrm{m}$ cellulose acetate disk filter. Equivalent calcium carbonate (\%) was determined by the volumetric method using a Bernard calcimeter (Plata et al., 2008). Organic carbon was determined by sulfochromic oxidation (Nelson and Sommers, 1982), according to the NF X 31-109 standard (AFNOR, 1993). Textural analysis was performed after dispersion of the fine soil and by

combining extraction by Robinson pipette and sieving. Soil samples were not previously decarbonated since almost all materials have a calcium carbonate matrix and silicate residue is very scarce.

The mineralogical composition was also determined. A semiquan- titative estimation of the mineralogical composition of the samples was made by Xray diffraction (XRD) analysis using $\mathrm{Cu}-\mathrm{K} \alpha$ radiation with a PW3040 Philips Diffractometer. X-powder software (Martín, 2004) was used to analyse the Xray diffraction diagrams obtained by the crystalline powder method. The powder diffraction file (PDF2) database was used for peak identification, taking into account that the determination of minerals from soils by XRD analysis is not accurate below a limit of $5 \%$ of the total weight in a sample (depending on the crystallinity of individualminerals).

To determine the selenium content, samples were first ground to a fine powder using a zirconium ball mill. After that, soil samples were placed in Teflon vessels and $5 \mathrm{ml}$ of concentrated HF acid solution, $200 \mu \mathrm{l}$ of concentrated $\mathrm{HNO}_{3}$ acid solution and $5 \mathrm{ml}$ of water were added. When digestion was complete (15 min at $1000 \mathrm{~W}$ in a Milestone ETHOS PLUS microwave oven), the sample was transferred to a volumetric flask and brought to $50 \mathrm{ml}$. The selenium content was 

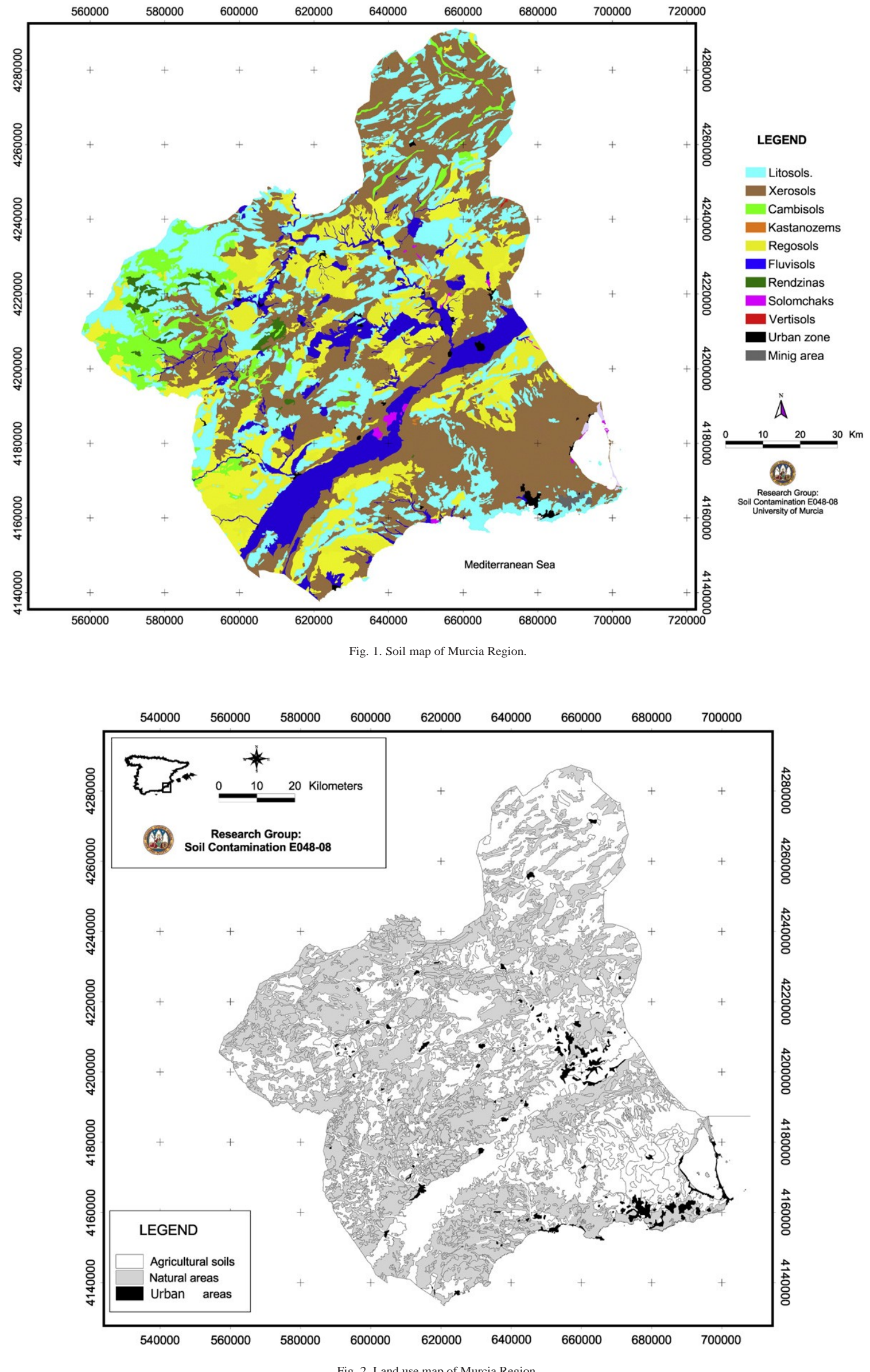

Fig. 2. Land use map of Murcia Region. 


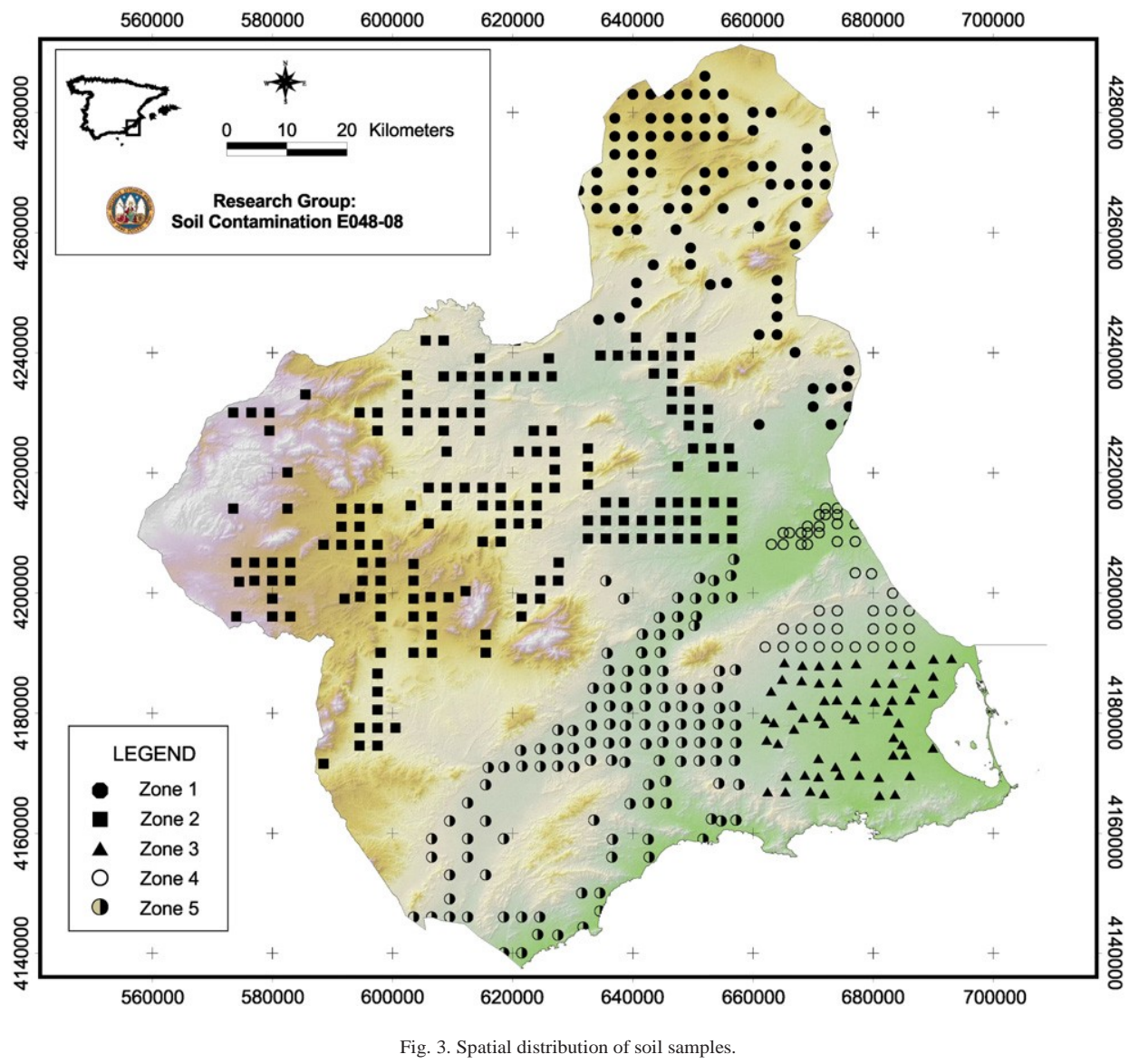

measured by atomic fluorescence spectrometry using an automated continuous flow hydride generation (HG-AFS) spectrometer (PSA Millenium Merlin 10025). The reliability of the results was verified through the analysis of four standard reference materials: standard reference material SRM 2711 Montana II Soil and SRM 2709 San Joaquin soil, NCS DC 73320 and NCS DC 73323, obtained from the China National Analysis Center for Iron and Steel (Beijing, China). Spikes, duplicates and reagent blanks were also used as part of quality assurance/quality control.

\subsection{Statistical analysis}

Descriptive statistics (mean, median, standard deviation, first and third quartile, interquartile range, maximum, minimum, frequency histogram and Anderson-Darling normality test) were determined using MINITAB software v15.

A multivariate analysis was also made for the variables, including correlation matrixes, discriminant analysis and variance analysis. A classification and a cluster analysis were made to determine whether the data obtained could be related significantly and so be used to divide the samples into groups. Then, assigning to each sample the variable of the group obtained by the cluster analysis, a discriminant analysis was applied to show the affinity of samples for one or more groups (Vidal et al., 2004). A correlation matrix was used to identify, firstly, the relationship between the selenium content and soil properties and lastly, between the selenium content and mineralogy in each studied zone. Pearson's product moment correlation coeffi- cient was used. Next, a one-way analysis of variance was made to establish the differences in the selenium content in the different mineralogical groups, previously established by way of a classificatory analysis for each zone.

\subsection{GIS methodology}

The sampling points, precisely defined by GPS, were integrated to create a database in which the coordinates and the value of the analytical characteristics for each point were included (Martínez-Sánchez and Pérez-Sirvent,2007).

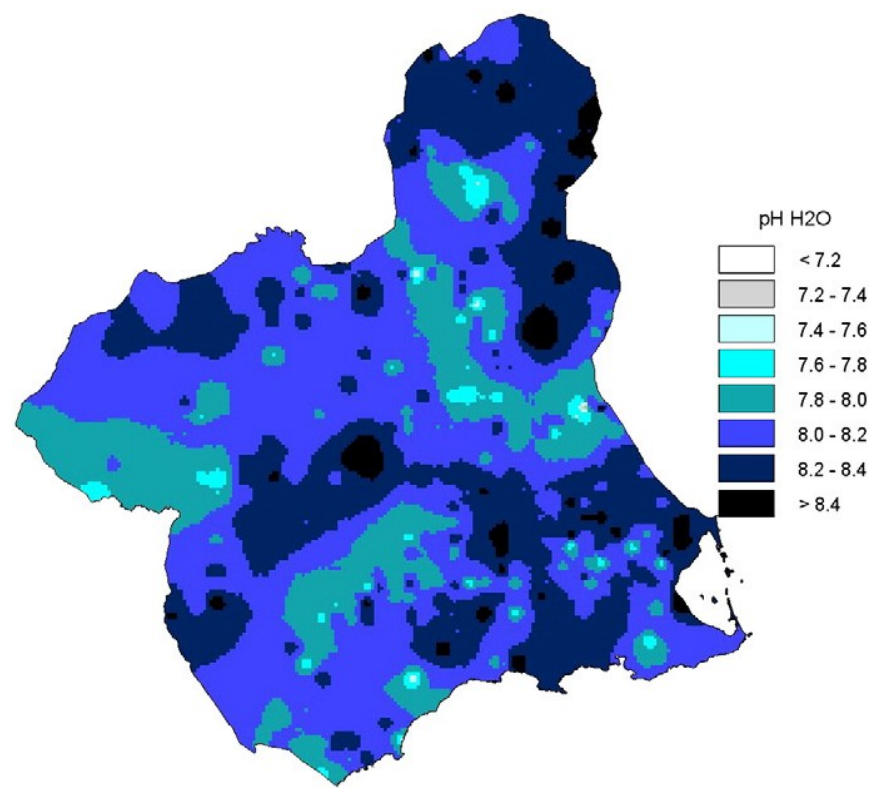

Fig. 4. Spatial distribution of $\mathrm{pH}$ results. 

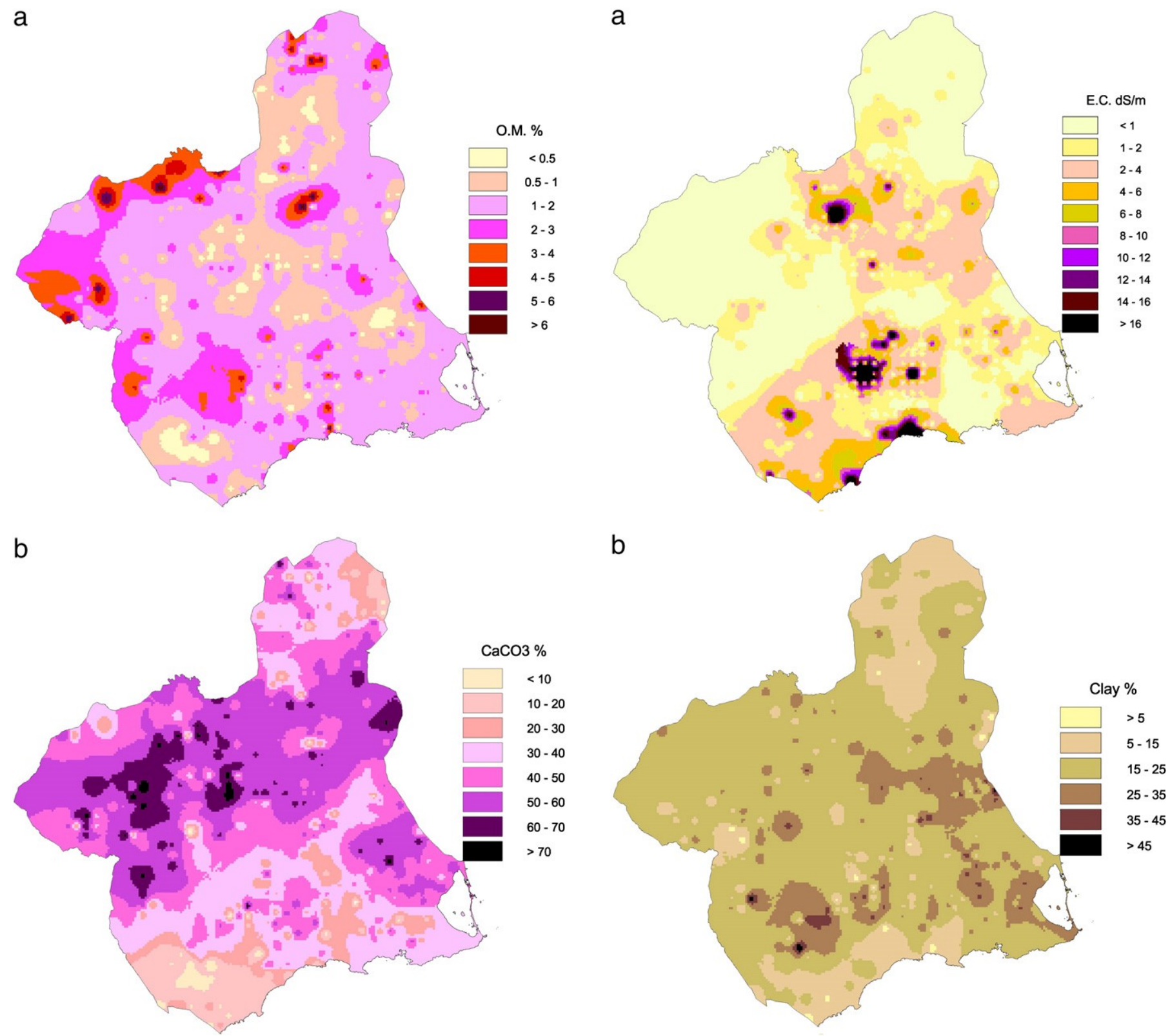

Fig. 5. Spatial distribution of organic matter content (a); and $\mathrm{CaCO}_{3}$ content (b).

Fig. 6. Spatial distribution of electrical conductivity (a) and clay content (b).

For the spatial distribution of the selenium content, 5 intervals were considered and soil samples were reclassified being included in oneinterval.

In order to reduce the cost of sampling and measurements for mapping, a spatial interpolation technique, kriging, is increasingly being used in contaminated sites. Kriging could be used with observed data to estimate the element concentration at unsampled locations (Juang et al., 2005). Ordinary kriging is a form of weighted local spatial interpolation that uses a Gaussian model to derive spatial estimates of variables supported by a data-set for the area being analysed (Cook et al., 2008).

Spatial interpolation and GIS mapping techniques were employed to produce spatial simulation maps for selenium. For this purpose, ArcGIS v.9 software was used. To make distribution maps, kriging was chosen to interpolate, owing to its several favourable properties. In ArcGIS, kriging can express the spatial variation and allow a variety of map outputs, including predictions, standard error prediction and probability, and at the same time minimize the errors of predicted values (Shi et al., 2008).

To minimize errors, the 12 nearest neighbour method was carried out. The last step was to reclassify the original maps into percen- tile maps, considering 5 intervals: (minimum — p25), (p25-p45),

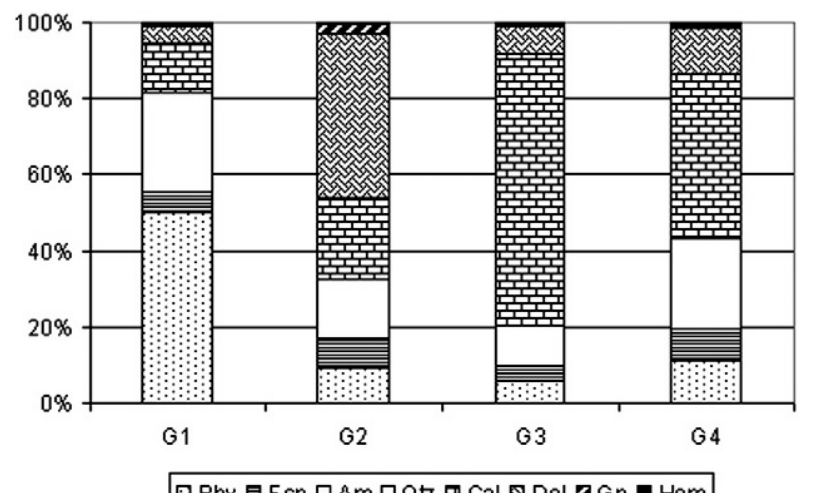

Fig. 7. Average mineralogical composition (\%) of groups. 


\begin{tabular}{|c|c|c|c|c|c|c|c|}
\hline & Mean & StDev & Minimum & Maximum & Q1 & Median & Q3 \\
\hline $\mathrm{pH} \mathrm{H} \mathrm{H}_{2} \mathrm{O}$ & 8.1 & 0.24 & 7.0 & 9.0 & 8.0 & 8.2 & 8.3 \\
\hline pHKCl & 7.5 & 0.22 & 6.5 & 8.4 & 7.3 & 7.5 & 7.6 \\
\hline $\mathrm{EC}\left(\mathrm{dS} \mathrm{m}{ }^{-1}\right)$ & 1.1 & 3.45 & 0.04 & 46.0 & 0.5 & 0.9 & 2.4 \\
\hline O.M (g $\left.100 \mathrm{~g}^{-1}\right)$ & 1.5 & 1.2 & 0.02 & 6.9 & 0.7 & 1.1 & 1.9 \\
\hline $\mathrm{CaCO}_{3}\left(\mathrm{~g} 100 \mathrm{~g}^{-1}\right)$ & 43.3 & 12.9 & 1.4 & 80.5 & 34.0 & 44.8 & 55.8 \\
\hline $\mathrm{F}^{-}\left(\mathrm{mg} \mathrm{l}^{-1}\right)$ & 4 & 16 & 0.5 & 133 & 0.5 & 2 & 3 \\
\hline $\mathrm{Cl}^{-}\left(\mathrm{mg} \mathrm{l}^{-1}\right)$ & 600 & 1240 & 52 & 8345 & 66 & 212 & 623 \\
\hline $\mathrm{NO}^{-}\left(\mathrm{mgl}^{-1}\right)_{3}$ & 617 & 1629 & 8 & 12,947 & 94 & 244 & 563 \\
\hline $\mathrm{SO}^{2-}\left(\mathrm{mgl}^{-1}\right)_{4}$ & 769 & 907 & 78 & 3620 & 119 & 337 & 1099 \\
\hline Se $\left(\mathrm{mg} \mathrm{kg}^{-1}\right)$ & 0.43 & 0.39 & 0.003 & 2.7 & 0.2 & 0.3 & 0.5 \\
\hline
\end{tabular}

Table 2

Mean values of some chemical parameters of the soil samples and selenium content in different zones of Murcia region ( $n=490)$

\begin{tabular}{|c|c|c|c|c|c|c|c|c|c|c|}
\hline & \multicolumn{2}{|c|}{ Zone 1} & \multicolumn{2}{|c|}{ Zone 2} & \multicolumn{2}{|c|}{ Zone 3} & \multicolumn{2}{|c|}{ Zone 4} & \multicolumn{2}{|c|}{ Zone 5} \\
\hline & Mean & StDev & Mean & StDev & Mean & StDev & Mean & StDev & Mean & StDev \\
\hline $\mathrm{pH} \mathrm{H}_{2} \mathrm{O}$ & 8.2 & 0.23 & 8.1 & 0.23 & 8.2 & 0.26 & 8.1 & 0.31 & 8.1 & 0.22 \\
\hline pHKCl & 7.6 & 0.20 & 7.4 & 0.21 & 7.5 & 0.22 & 7.3 & 0.24 & 7.5 & 0.24 \\
\hline $\mathrm{EC}\left(\mathrm{dS} \mathrm{m}^{-1}\right)$ & 0.9 & 1.25 & 1.9 & 4.46 & 2.6 & 1.54 & 2.7 & 2.37 & 6.7 & 1.99 \\
\hline $\mathrm{O} . \mathrm{M}\left(\mathrm{g} 100 \mathrm{~g}^{-1}\right)$ & 1.3 & 1.20 & 1.6 & 1.41 & 1.3 & 0.57 & 1.4 & 1.00 & 1.4 & 1.17 \\
\hline $\mathrm{CaCO}_{3}\left(\mathrm{~g} 100 \mathrm{~g}^{-1}\right)$ & 40.9 & 16.15 & 53.3 & 14.21 & 39.3 & 12.81 & 37.5 & 11.96 & 31.7 & 15.70 \\
\hline Se $\left(\mathrm{mg} \mathrm{kg}^{-1}\right)$ & 0.27 & 0.09 & 0.35 & 0.11 & 0.78 & 0.46 & 0.85 & 0.55 & 0.31 & 0.46 \\
\hline
\end{tabular}

(p45-p65), (p65-X+2s) and (X+2s - maximum) (Pérez-Sirvent etal., 2009).

In addition, a validation of the spatialization simulation was carried out. For that, a $10 \times 10 \mathrm{~km}$ systematic grid was superimposed on the original 3 $\times 3 \mathrm{~km}$ grid. For the spatial simulation validation, points located on the square corners were selected, whose values correspond to those of the nearest point. The validation of spatializa- tion simulation was carried out putting apart $10 \%$ of the initial values, randomly selected, and these data were used to validate simulations. Finally, frequency histograms of the initial and validation values have been compared, assuming as valid a smaller deviation of $10 \%$.

\section{Results and discussion}

\subsection{Results from previous studies}

Previous studies carried out in Murcia Region (Martínez-Sánchez and Pérez-Sirvent, 2007) showed that soils showed basic $\mathrm{pH}$ values (Fig. 4). Highest $\mathrm{pH}$ values correspond to soils with a high carbonate content and, above all, if they are finely divided.

Generally, soils showed a low organic matter content, but well humified (Fig. 5a). Spatial distribution of the calcium carbonate

content is in accordance with the parent material. Zones 2 and 1 showed the highest values of calcium carbonate content, corresponding to abundance of petrocalcic Xerosols, Litosols and calcaric Regosols. In zones 3 and 4, lower calcium carbonate corresponds to almost decarbonated paleosoils (calcic Luvisols). In zone 5, soils developed over metamorphic (lithosolic Litosols) or volcanic rocks showed the lowest calcium carbonate values (Fig. 5b).

Table 3

Textural of the soil samples $\left(\mathrm{g} 100 \mathrm{~g}^{-1}\right)$. Statistical estimates $(\mathrm{n}=490)$.

\begin{tabular}{lrrcrrrr}
\hline & Mean & StDev & Minimum & Maximum & Q1 & Median & Q3 \\
\hline b2 $\mu \mathrm{m}$ & 20.1 & 8.7 & 0.0 & 54.0 & 14.2 & 19.5 & 25.1 \\
$2-50 \mu \mathrm{m}$ & 42.9 & 13.5 & 0.0 & 68.7 & 36.2 & 45.0 & 52.0 \\
$50-500 \mu \mathrm{m}$ & 29.3 & 15.2 & 0.0 & 85.1 & 19.5 & 28.7 & 37.1 \\
$500-2000 \mu \mathrm{m}$ & 5.9 & 6.3 & 0.0 & 51.1 & 1.2 & 4.1 & 7.6 \\
\hline
\end{tabular}

Fig. 6a showed electrical conductivity results in Murcia Region. Only a few sampling points showed electrical conductivity values higher than 2 $\mathrm{dS} / \mathrm{m}$, corresponding to Solonchaks, Regosols or saline phase Fluvisols. Fig. 6b showed spatial distribution of the clay content. Highest values correspond to calcic Luvisols, luvic Xerosols, some Fluvisols, Cambisols and Regosols. Highest values were foundinzones 2 and 5 .

Finally, previous statistical analysis allowed establishing four groups with different mineralogical compositions (Fig. 7), and each sample was located in one group (Martínez-Sánchez and Pérez-Sirvent, 2007).

\subsection{Analytical results}

According to our sampling design (Section 2.1), sampling points for generic reference level determination are summarised in Fig. 3.

The main soil properties results are shown in Tables 1 and 2. Soil samples showed basic $\mathrm{pH}$ with a mean value of 8.1 and a low organic matter content. The mean value for the calcium carbonate content was $43.3 \%$ and EC values ranged from 0.04 to $46 \mathrm{dS} \mathrm{m}^{-1}$, with an average value of $1.1 \mathrm{dS} \mathrm{m}^{-1}$. Soils with a high calcium carbonate content had a low organic matter content. Soluble salt content results are also shown in Table 1 and indicated that the average value was $4 \mathrm{mgl}^{-1}$ for $\mathrm{F}$,

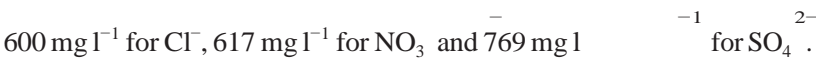

Table 4

Mineralogical composition (\%) of the soil samples. Statistical estimates ( $\mathrm{n}=490)$

\begin{tabular}{lrrccrrr}
\hline & Mean & StDev & Minimum & Maximum & Q1 & \multicolumn{3}{c}{ Median } & Q3 \\
\hline Phyllosilicate & 10.0 & 12.5 & 0.0 & 64.0 & 3.0 & 5.0 & 10.0 \\
Phyllosilicate 14 $\AA$ & 2.4 & 8.2 & 0.0 & 61.0 & 0.0 & 1.0 & 2.0 \\
Phyllosilicate $10 \AA$ & 8.7 & 11.8 & 0.0 & 61.0 & 2.0 & 4.0 & 8.0 \\
Phyllosilicate $\AA \AA$ & 1.5 & 7.3 & 0.0 & 56.0 & 0.0 & 0.0 & 1.0 \\
Feldspars & 4.7 & 4.9 & 0.0 & 42.0 & 2.0 & 3.0 & 6.0 \\
Amphibole & 0.1 & 0.6 & 0.0 & 8.0 & 0.0 & 0.0 & 0.0 \\
Quartz & 15.3 & 10.0 & 0.0 & 53.0 & 8.0 & 12.0 & 20.5 \\
Calcite & 54.8 & 22.0 & 1.0 & 95.0 & 41.5 & 60.0 & 72.0 \\
Dolomite & 11.4 & 12.5 & 0.0 & 68.0 & 3.0 & 8.0 & 15.0 \\
Gypsum & 0.5 & 2.5 & 0.0 & 26.0 & 0.0 & 0.0 & 0.0 \\
Hematite & 0.6 & 0.7 & 0.0 & 7.0 & 0.0 & 0.0 & 1.0 \\
\hline
\end{tabular}




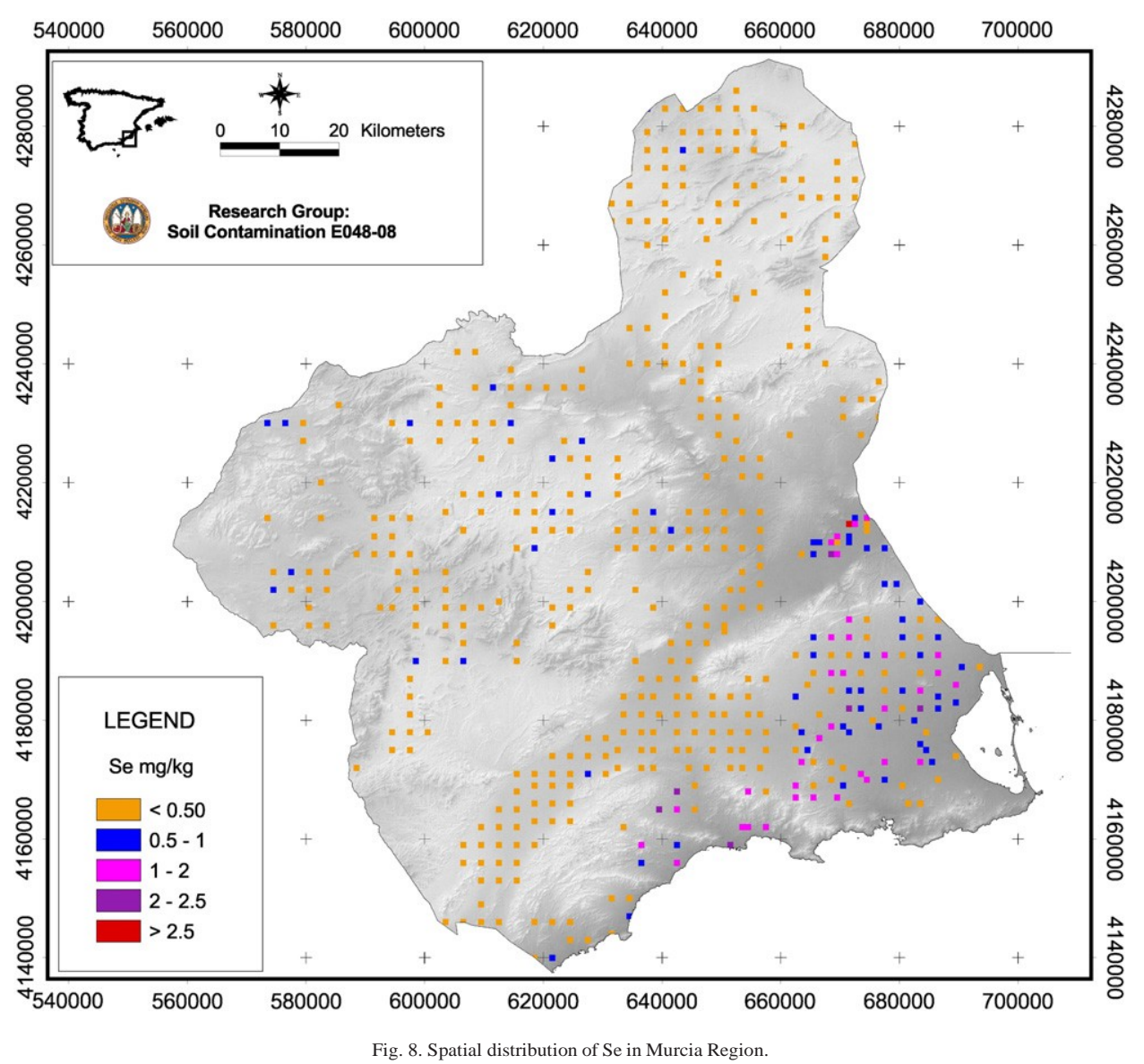

Analytical results in the different zones showed that $\mathrm{pH}$ values and organic matter content was similar in the 5 established zones, while the calcium carbonate content was higher in zones 1 and 2 (Table 2). The textural analysis is shown in Table 3 and indicated that the major soil texture was sandy loam and the samples ranged from a loamy sand texture to a silty clay texture. Table 4 shows the statistical results for the mineralogical composition. The mineralogical compo- sition is characterised by high calcite, quartz, phyllosilicates and dolomite content. The samples also present feldspars, hematite,

gypsum and amphiboles in a low content.

Finally, selenium values ranged from $0.003 \mathrm{mg} \mathrm{kg}^{-1}$ to $2.7 \mathrm{mg} \mathrm{kg}^{-1}$ (Table 1), with an average value of $0.4 \mathrm{mg} \mathrm{kg}^{-1}$. The average selenium content showed is similar in zones 1, 2 and 5, while in zones 3 and 4 the average selenium content was higher (Table 2). Spatial distribution of the selenium content in Murcia Region is shown in Fig. 8.

\subsection{Multivariate analysis results}

The multivariate analysis was used to study the relationship between the selenium content, mineralogical composition and the rest of studied soil parameters.

Pearson correlation analysis results demonstrated that in zones 1 and 2 the selenium content was only correlated positively with electrical conductivity $(\mathrm{r}=0.410, \mathrm{p}=0.009$ in zone 1 and $\mathrm{r}=0.527, \mathrm{p}=0.011$ in zone 2) and sulphate content ( $r=0.666, p=0.007$ in

Table 5

Selenium content in agricultural soil samples $(n=415)$ and soils with natural vegetation (abandoned agricultural areas) $(\mathrm{n}=75)$.

\begin{tabular}{lllll}
\hline & Mean & StDev & Minimum & Maximum \\
\hline Se $\left(\mathrm{mg} \mathrm{kg}^{-1}\right)$ & 0.37 & 0.16 & 0.0033 & 4.7 \\
Se $\left(\mathrm{mg} \mathrm{kg}^{-1}\right)$ & 0.31 & 0.15 & 0.0027 & 3.5 \\
\hline
\end{tabular}

zone 1 and $r=0.711, p=0.002$ in zone 2). Moreover, in zone 2, the Se content was also positively correlated with quartz $(r=0.399, p=0.026)$ and negatively correlated with the calcite content $(\mathrm{r}=$

$-0.443, p=0.012$ ). In zone 3 , Se was not correlated with any soil characteristic, soil texture or mineralogical composition. In zone 4, Se was positively correlated with electrical conductivity $(\mathrm{r}=0.468, \mathrm{p}=0.019)$, sulphate content $(\mathrm{r}=0.558, \mathrm{p}=0.015)$ and with phyllo- silicate content $(\mathrm{r}=$ $0.512, \mathrm{p}=0.008$ ). Finally, in zone 5 , Se was positively correlated with the phyllosilicate content $(r=0.509, \mathrm{p}=0.011)$, positively correlated with quartz percentage $(r=0.592)$, and negatively correlated with the calcite content $(r=-0.429$, $\mathrm{p}=0.022$ ), as in zone 2 .

The positive correlation between the selenium content and the electrical conductivityis due to selenium that is associated to the soluble

Table 6

Selenium GRL in the different mineralogical groups.

\begin{tabular}{|c|c|c|}
\hline & & Se $(\mathrm{mg} / \mathrm{kg})$ \\
\hline \multirow[t]{4}{*}{ Zone 1} & G1 & 0.5 \\
\hline & G2 & 0.4 \\
\hline & G3 & 0.5 \\
\hline & G4 & 0.4 \\
\hline \multirow[t]{4}{*}{ Zone 2} & G1 & 0.6 \\
\hline & G2 & 0.6 \\
\hline & G3 & 0.6 \\
\hline & G4 & 0.6 \\
\hline \multirow[t]{2}{*}{ Zone 3} & G3 & 1.8 \\
\hline & G4 & 1.5 \\
\hline \multirow[t]{2}{*}{ Zone 4} & G3 & 1.6 \\
\hline & G4 & 2.3 \\
\hline \multirow[t]{4}{*}{ Zone 5} & G1 & 1.2 \\
\hline & G2 & 0.9 \\
\hline & G3 & 0.5 \\
\hline & G4 & 2.4 \\
\hline
\end{tabular}




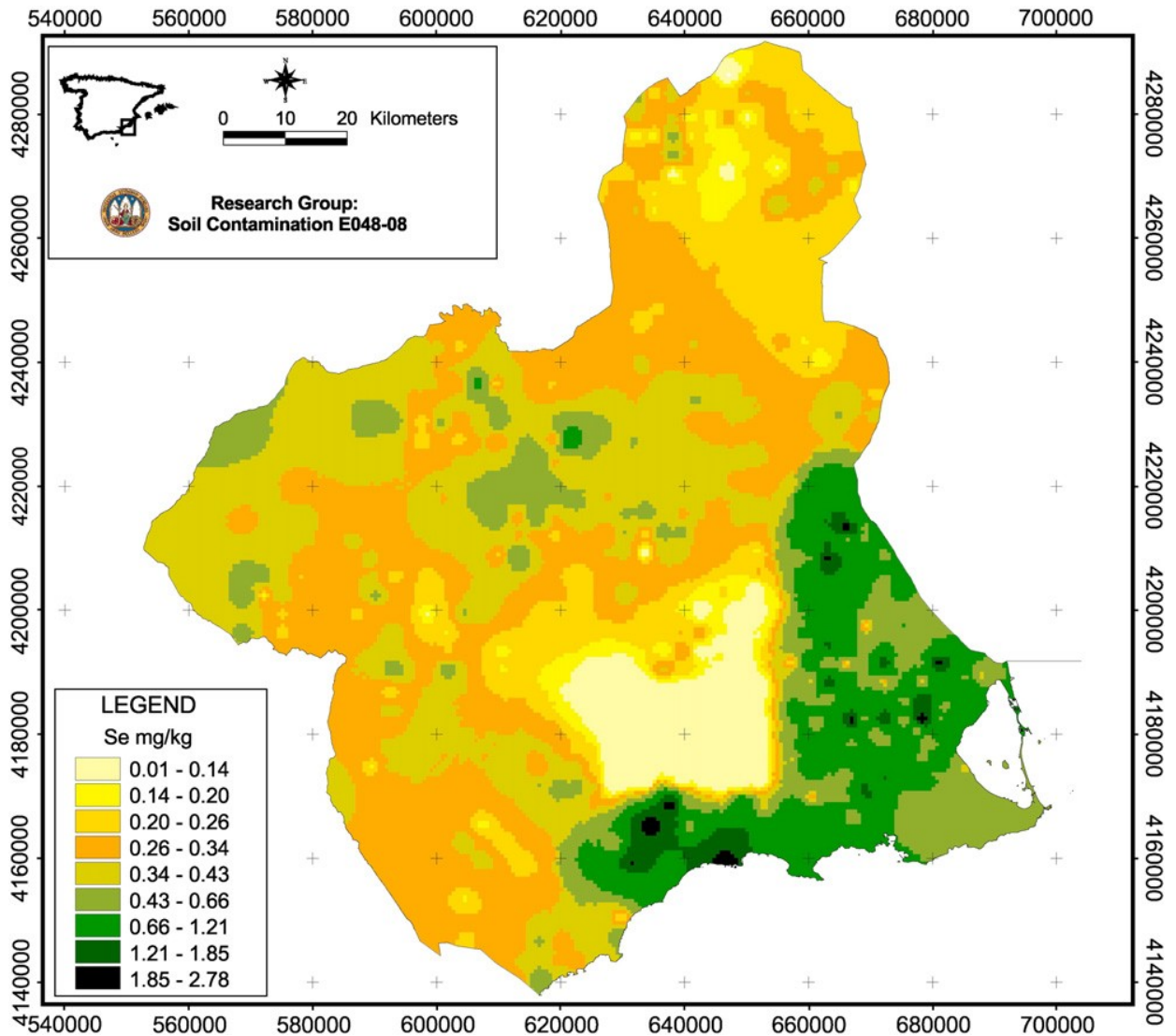

Fig. 9. Spatial simulation of selenium concentration ( $\mathrm{mg} \mathrm{kg}^{-1}$ ).

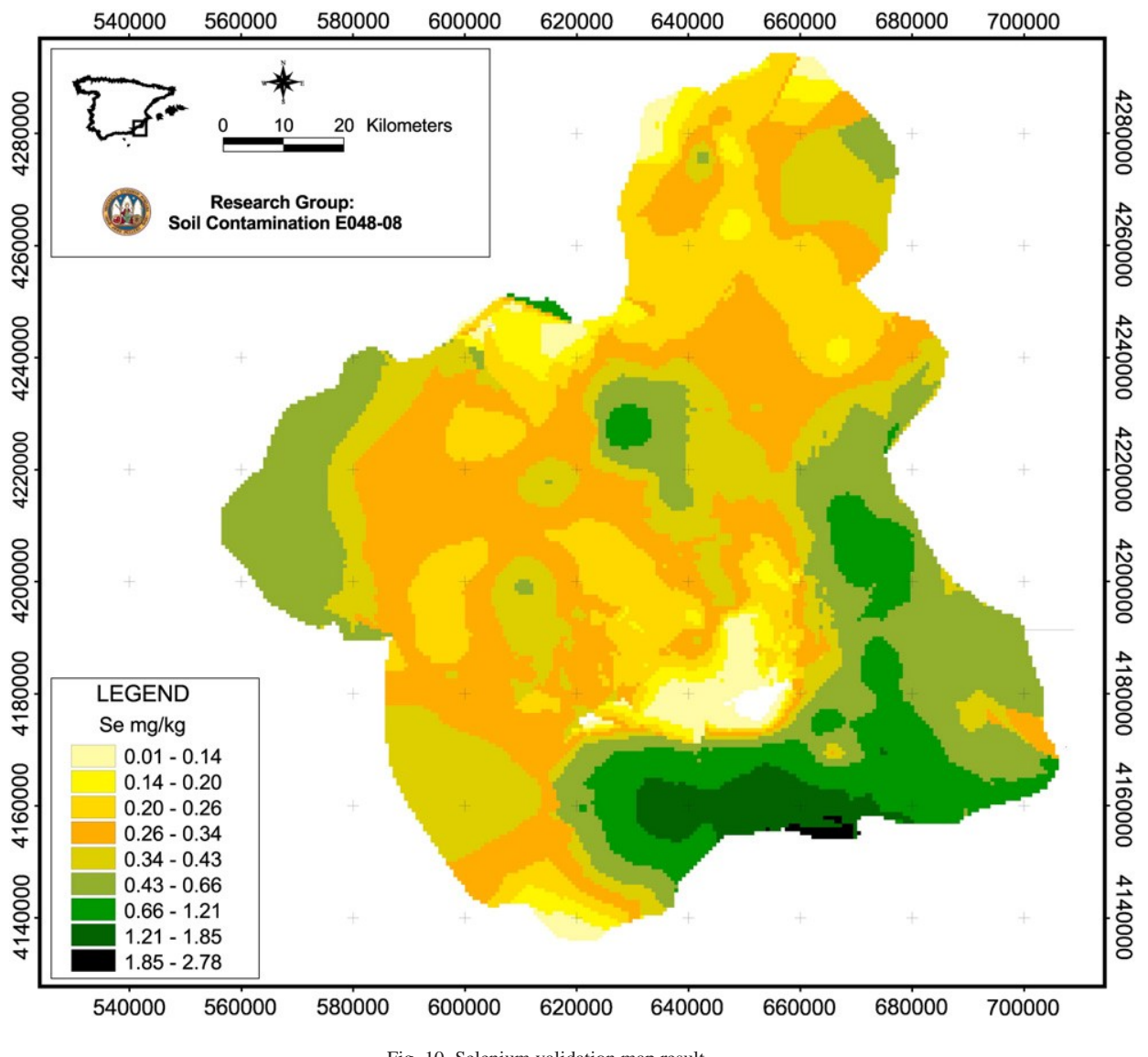

Fig. 10. Selenium validation map result. 
Table 7

Se concentration within the established intervals for $3 \times 3 \mathrm{~km}(1, \mathrm{n}=490)$ and $10 \times 10 \mathrm{~km}$ $(2, \mathrm{n}=49)$ sampling.

\begin{tabular}{lcc}
\hline Se $\left(\mathrm{mg} \mathrm{kg}^{-1}\right)$ & 1 & 2 \\
\hline $0.01-0.14$ & $5 \%$ & $3 \%$ \\
$0.14-0.20$ & $3 \%$ & $4 \%$ \\
$0.20-0.26$ & $13 \%$ & $16 \%$ \\
$0.26-0.34$ & $30 \%$ & $27 \%$ \\
$0.34-0.43$ & $24 \%$ & $18 \%$ \\
$0.43-0.66$ & $12 \%$ & $19 \%$ \\
$0.66-1.21$ & $11 \%$ & $9 \%$ \\
$1.21-1.85$ & $2 \%$ & $3 \%$ \\
$1.85-2.78$ & $0.3 \%$ & $0.4 \%$ \\
\hline
\end{tabular}

salt content, particularly to sulphates, which are usual in marls from Keuper, present in many areas of the studied zone. In addition, marls present a high clay content, which explains the correlation between selenium and phyllosilicate content. On the other hand, some areas in the studied zone do not present marls. In these areas, the positive correlation between selenium and phyllosilicates is due to phyllite occurrence, which also presents a high clay content. Phyllite presence mainly occurs in zones 4 and 5, where soils were developed over metamorphic materials from the Alpujárride complex.

An analysis of variance was carried out in order to study the variations between agricultural soils and soils with natural vegetation (corresponding to abandoned agricultural areas). Of the total number of samples, 415 corresponded to soils devoted to agricultural activities whereas 75 were covered with natural vegetation as a result of being abandoned. The results pointed to no differences in the selenium content according to soil use (p-valueN0.05) (Table 5).

Another analysis of variance was proposed to study the differences in the selenium content in the different mineralogical groups. Almost all the samples were included in groups 3 and 4, whereas the group presenting fewest samples was group 1. Multivariate Kruskal-Wallis test-results showed that the selenium p-value was higher than the significance level $(0.05)$ for zones 1 , 2 and 3 , meaning that the selenium content does not change in the different groups established, while in zones 4 and 5 , the p-value was lower than the significance level, indicating that selenium content changes in the different mineralogicalgroups.

\subsection{Determination of generic reference level}

Generic reference levels in the five different zones and different mineralogical group are shown in Table 6 . The selenium content was different in the same mineralogical group in the different study areas. On the other hand, in zones 4 and 5 , the selenium content showed statistically significant differences as a function of the mineralogical group.

Fig. 9 show the spatial simulation results of selenium in the studied area. The frequency of samples showing extreme values (higher than GRL) was 2\%. The results of validation of the spatial simulations suggested that when geographical distributions of the Se content are compared (all soil samples compared with $10 \%$ randomly selected for validation), the variation is lower than $10 \%$ (Fig. 10 and Table 7).

\section{Conclusions}

Selenium levels in Murcia Region soils are similar to those values found in other non-contaminated world soils developed over limestones and metamorphic materials (phyllites and shales) (Kabata-Pendias and Mukherjee, 2007). The obtained results allow deducing that selenium GRL could be determined taking into account lithological characteristics and the geographical area where soils are located.
Correlation analysis results shows that the selenium content in soil samples from Murcia Region was related with the electrical conductivity, sulphate content and with the phyllosilicate content, particularly with metamorphic materials from the Alpujárride complex.

It is important to highlight the fact that, in Spain, GRL calculation for each mineralogical group has a great transcendence from the legal and economic points of view. If the established criteria of considering a soil as contaminated if determined concentration exceeds 100 or more times the established GRL, differences in our case could be more than five times the concentration, according to its lithology (mineralogical group) and the geographical area, with the consequent economic and environmental negative repercussions for its recuperation.

\section{Acknowledgments}

The authors are grateful to the Environmental Government of Region of Murcia and to the Spanish Ministerio de Educación y Ciencia (CTM2008-04567, MEC, 008-2011). Mari Luz García-Lorenzo also acknowledges a fellowship from Fundación Séneca.

\section{References}

Adriano, D.C., 2001. Trace Elements in Terrestrial Environments: Biogeochemistry, Bioavailability and Risks of Metals, 2nd edition. Springer-Verlag, New York.

AFNOR, 1993. Norme française NF X 31-109. Qualité des sols. Méthodes chimiques. Détermination du carbone organique par oxidation sulfochromique.

Albanese, S., De Vivo, B., Lima, A., Cicchella, D., 2007. Geochemical background and baseline values of toxic elements in stream sediments of Campania region (Italy). Journal of Geochemical Exploration 93, 21-34.

CARM, Consejería de Agricultura, Agua y Medio Ambiente., 1999. Mapa Digital de Suelos de la Región de Murcia.

Cook, S.E., Jarvis, A., Gonzalez, J.P., 2008. A new global demand for digital soil information. In: Hartemink, A.E., McBratney, A., Mendonça-Santos, M.L. (Eds.), Digital Soil Mapping with Limited Data. Springer.

De Temmerman, L.O., Hoenig, M., Scokart, P.O., 1984. Determination of normal Q levels and upper limit values of trace elements in soils. Zeitschrift fuer Pflanzenernaehrung und Bodenkunde 147, 687694.

Ferguson, J.E., 1990. The Heavy Elements: Chemistry, Environmental Impact and Health Effects. Pergamon Press, Oxford.

Ferguson, C., Kasamas, H., 1999. Risk assessment for contaminated sites in Europe. Policy Framework, volume 2. LQM Press, Nottingham.

Horckmans, L., Swennen, R., Deckers, J., Maquil, R., 2005. Local background concentrations of trace elements in soils: a case study in the Grand Duchy of Luxembourg. Catena 59, 279-304.

Juang, K.W., Lee, D.Y., Teng, Y.T., 2005. Adaptive sampling based on the cumulative distribution function of order statistics to delineate heavy-metal contaminated soils using kriging. Environmental Pollution 138 (2), 268-277.

Kabata-Pendias, A., Mukherjee, A.B., 2007. Trace Elements from Soil to Human. Springer, Heidelberg.

Klassen, R.A., 1998. Geological factors affecting the distribution of trace metals in glacial sediments of central Newfoundland. Environmental Geology 33, 154-169.

Lauchli, A., 1993. Selenium in plants: uptake, functions, and environmental toxicity. Botanica Acta 106, 455-468.

Martín, D., 2004. Qualitative, Quantitative and Microtextural Powder X-ray Diffraction Analysis. http://www.xpowder.com.

Martínez, J., Llamas, J., De Miguel, E., Rey, J., Hidalgo, M.C., 2007. Determination of the geochemical background in a metal mining site: example of the mining district of Linares (South Spain) Journal of Geochemical Exploration 94, 19-29.

Martínez-Sánchez, M.J., Pérez-Sirvent, C., 2007. Niveles de fondo y niveles genéricos de referencia de metales pesados en suelos de la Región de Murcia. Consejería de Desarrollo sostenible y Ordenación del territorio, Murcia.

Micó, C., Peris, M., Recatalá, L., Sánchez, J., 2007. Baseline values for heavy metals in agricultural soils in a European Mediterranean region. Science of the Total Environment 378, 13-17.

Nelson, D.W., Sommers, L.E., 1982. Total carbon, organic carbon, and organic matter. Methods of soil analysis: In: Page, A.L. (Ed.), Part 2, American Society of Agronomy and Soil Science Society of America.

Pérez-Sirvent, C., Martínez-Sánchez, M.J., García-Lorenzo, M.L., Molina, J., Tudela, M.L., 2009. Geochemical background levels of zinc, cadmium and mercury in anthro- pically influenced soils located in a semi-arid zone (SE, Spain). Geoderma 148, 307-317.

Plata, M.R., Hernando, J., Zougagh, M., Contento, A.M., Villaseñor, M.J., Sánchez-Rojas, J.L., Ríos, A., 2008. Characterization and analytical validation of a microcantilever-based sensor for the determination of total carbonate in soil samples. Sensors and actuators 134, 245-251.

Salminen, R., Gregorauskiene, G., 2000. Considerations regarding the definition of a geochemical baseline of elements in the superficial materials in areas differing in the geology. Applied Geochemistry 15, 647-653. 
Salminen, R., Tarvainen, T., 1997. The problem of defining geochemical baselines. A case study of selected elements and geological materials in Finland. Journal of Geochemical Exploration 60, 91-98.

Schwartz, K., Foltz, C.M.J., 1957. Selenium as an integral part of factor 3 against necrotic liver degeneration. Journal of the American Chemical Society 79, 3292-3293.

Shi, G., Chen, Z., Xu, S., Zhang, J., Wang, L., Bi, C., Teng, J., 2008. Potentially toxic metal contamination of urban soils and roadside dust in Shanghai, China. Environmental Pollution 156, 251-260.

Spanish Royal Decree 9/2005, de 14 de enero, por el que se establece la relación de actividades potencialmente contaminantes del suelo y los criterios y estándares para la declaración de suelos contaminados.

Su, Y.-Z., Yang, R., 2008. Background concentrations of elements in surface soils and their changes as affected by agriculture use in the desert-oasis ecotone in the middle of Heihe River Basin, North-west China. Journal of Geochemical Exploration 98, 57-64. Tack, F.M.G., Verloo, M.G., Vanmechelen, L., Van Ranst, E., 1997. Baseline concentration levels of trace elements as a function of clay and organic carbon content in soils in Flanders (Belgium). Science of the Total Environment 201, 113-123.

Vidal, J., Pérez-Sirvent, C., Martínez-Sánchez, M.J., Navarro, M.C., 2004. Origin and behaviour of heavy metals in agricultural Calcaric Fluvisols in semiarid conditions. Geoderma 121, 257270.

Xue, T., Hartikainen, H., Piironen, V., 2001. Antioxidative and growth-promoting effect of selenium on senescing lettuce. Plant and Soil 237, 55-61. 